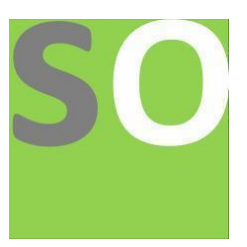

Article title: EMT and Political Reform Effects on Chinese Markets: A Literature Review Authors: Luigi Gallo[1]

Affiliations: Università degli studi della Tuscia[1]

Orcid ids: 0000-0001-5973-5704[1]

Contact e-mail: Ig.luigigallo@gmail.com

License information: This work has been published open access under Creative Commons Attribution License http://creativecommons.org/licenses/by/4.0/, which permits unrestricted use, distribution, and reproduction in any medium, provided the original work is properly cited. Conditions, terms of use and publishing policy can be found at https://www.scienceopen.com/.

Preprint statement: This article is a preprint and has not been peer-reviewed, under consideration and submitted to ScienceOpen Preprints for open peer review.

DOI: 10.14293/S2199-1006.1.SOR-.PP3QBMW.v2

Preprint first posted online: 14 April 2021

Keywords: China, Financial, Stock, Market, Markets, Efficient, Theory, Hypothesis, Fama, Correlation 


\section{EMT and Political Reform Effects on Chinese Markets: A Literature Review}

Luigi Gallo

Email:1g.luigigallo@gmail.com

Index

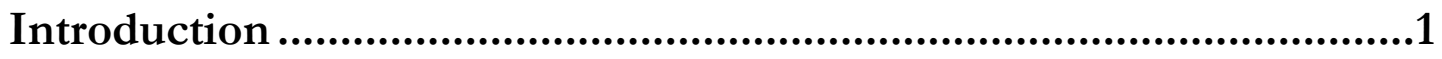

Efficient Market Hypothesis ...........................................................1

Review of the Literature on Efficient Market Theory in China .......... 2

Literature Review on Regulatory Changes ..........................................12

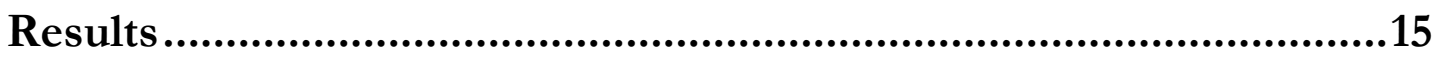

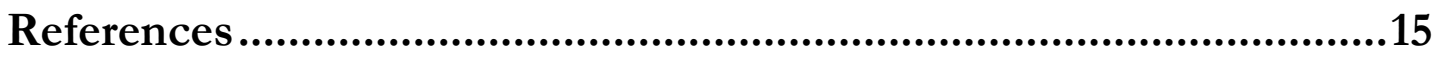

\section{Introduction}

The objective of this paper is to analyse the literature on and the evolution of the analysis of Chinese financial markets over time. Seven papers, based mainly on Efficient Market Theory (Fama, 1998) and the correlation between different markets, published in the years 1999-2019, have been selected and compared as they analyse data taken from the Shenzhen and Shanghai markets.

\section{Efficient Market Hypothesis}

The efficient market hypothesis (EMH) assumption is that information is shared and that stock prices follow a random walk, so they are determined by the latest news.

The EMH is differentiated into three forms: weak, semi-strong and strong. The weak form of the theory states that public market information is reflected totally in prices. The semi-strong form says that stock prices are updated to reflect both market and non-market public information. The strong form states that prices reflect all public and private information.

The assumptions about information underlying EMH vary depending on the form, with the weak form of the hypothesis assuming that only public market 
information is known to all market participants, the strong form presuming perfect information transparency. In all forms, future stock price movements are independent of past stock price fluctuations.

At the time of Fama's theory, the idea of market efficiency became popular among academics but not between professionals. This situation changed in 1973 when B. Malkiel's book, "A Random Walk Down Wall Street", was published. The EMH spread from academics to professionals, according to Shiller (2003), but this caused a market efficiency paradox: the more EMT is trusted by investors, the less efficient it becomes (Grossman and Stiglitz, 1976).

Grossman claimed that if there is a strong consensus that the market is efficient, the participants begin to act passively and cease to collect information, which would lead to inefficiency (Degutis and Novickytè, 2014).

The EMH describes perfectly trading conditions in the modern stock market because the information flows and trade movements are faster than ever, but, there are some patterns in stock prices which the EMH fails to explain (Shiller, 2013).

\section{Review of the Literature on Efficient Market Theory in China}

In "An Empirical Analysis of the Equity Markets in China", Mookerjee and $\mathrm{Yu}(1999)$ tested the market efficiency of the newly established stock markets in Shanghai and Shenzhen. They worked with daily stock price data and a battery of tests like the correlation test and a simulation of a random-walk trend based on Fama's random-walk hypothesis. This paper aimed to test the EMT on the Chinese stock market and the presence of seasonal fluctuations in that. The authors used data collected from 1990 to 1993 for the Shanghai stock market and from 1991 to 1993 for the Shenzhen one. Before the statistic test for market efficiency, the authors presented and discussed the statistical profile of daily stock returns on both Shanghai and Shenzhen exchanges. For both, daily stock returns were not normal, evidenced by kurtosis and skewness statistics. 
After conducting the statistical analysis, in the report, the authors performed an empirical analysis based on three popular tests of serial independence in daily stock returns.

The first one is the Serial correlation test, inspired by Fortune (1991), conducted jointly with the EMH test. The daily closing stock price indices failed to support the random walk hypothesis for both exchanges. The second test was the runs test to check for the randomness of stock prices on the two exchanges. A sequence of consecutive stock price changes in the same direction defined a run; typically, there were two runs, up or down. In the conclusion, the authors could not reject the randomness. The third test was the nonparametric distribution-free test for serial correlation, which report, as expected, the rejection of null-hypothesis of serial independence.

After this series of statistical tests, the working paper studied the seasonal anomalies on the Shanghai and Shenzhen exchanges. These anomalies were much more significant during the weekend or holiday, but not in January. Hence, in China, there was no influence of the January effect, a diffused phenomenon of the most important markets in the World (Mookerjee and $\mathrm{Yu}, 1999)$.

Five years later, Cajueiro and Tabak (2004), conducted similar research to demonstrate that the Chinese, Hong-Kong and Singapore markets have long-term memory dependence. After a brief introduction, the authors explain their methodology to calculate long-range dependence. They based their work on the R/S analysis, which was the most popular way to measure and detect the aim of the working paper and the Hurst exponent. The study compared three different stock markets, the Chinese, Hong Kong, and Singapore one.

They analysed A and B-shares traded from 1992 to 2000 in the Chinese stock market, and the information transmission effects. They compared the Singapore and Hong Kong markets because they were developed countries.

In the assumption that there was asymmetric information, caused by the institutional investors that had better information than the other players in the market, the weak-form efficiency characterised the market.

The authors used the daily returns for all the market share, also studying the Hong Kong index Hang Seng and the straits time index for Singapore.

In this journal article, Cajueiro and Tabak followed two approaches: they first used a statical approach to calculate the Hurst exponent for the entire series; then, they considered a "rolling sample" approach. The methods indicated 
different results, not comparable to each other. To study the Hurst exponent coherently with the calculations, the authors made a statistical inference.

In their conclusions, the three markets analysed until 2000 showed the presence of long-range dependence and the most inefficient indices appear to be the B-shares for China and Singapore. The authors also added that these phenomena should be studied in-depth and over time (Cajueiro and Tabak, 2004).

Under another perspective, the work of da Veiga, Chan and McAleer (2008) analysed the Chinese $\mathrm{A}$ and $\mathrm{B}$-shares, to investigate the time-varying conditional correlations between them, using the Dynamic Conditional Correlation (DCC) model (Engle, 2002). The aim of the paper is explained in the introduction, which also contains references to past similar works.

All the studies mentioned in this text suggest that the B-share reform of the Chinese market had a significant impact on the covariance matrix between $\mathrm{A}$ and B-shares, which, even today, is the most significant input in most financial applications, such as risk management, asset pricing and portfolio construction.

Another aspect analysed in all these works is the study of information flow between the two Chinese markets. Chui and Kwok (1998) work demonstrated that the returns of B-shares lead to the returns of A-shares, due to asymmetric information and information flows.

The aim of the paper written by da Veiga, Chan and McAleer, was to examine the impact of the recent B-share market reform on the correlation dynamics between A and B-shares issued in the same market, by estimating the Dynamic Conditional Correlation model. The chosen data were the daily returns for the Shanghai A-share index, Shanghai B-share index, Shenzhen A-share index, and Shenzhen B-share index, from 1992 to 2005. In section 3, the authors presented Engle's condition volatility approach (Engle, 2002), which was used to determine a random walk to simulate the dynamic correlations between A and B-shares in the Shanghai and Shenzhen markets. The result of empirical tests showed that the correlations increased substantially after the B-share market reform but started before it. The results had significant implication relating to the structure of the information flow between the markets; therefore, da Veiga, Chan and McAleer also calculated the Value-at-Risk (VaR).

VaR threshold forecasts are used to analyse the importance of accommodating dynamic conditional correlations between Chinese A and B- 
shares, and thus they reflect the impact of the changes in the information flow on the risk evaluation of a diversified portfolio (da Veiga, Chan and McAleer, 2008).

The fourth academic paper, here analysed, came after five years from Cajueiro and Tabak's (2004) work and its objective was the same: to study, using the single and multiple variance ratio tests, the EMH weak-form of A and B-shares on Shanghai and Shenzhen markets. Hung's (2009) work examined the influence of the reform on investment restriction of the Bshares market on market efficiency. For the empirical test, Hung used the pioneering work of Andrew W. Lo and A. Craig MacKinlay (1988), known as LOMAC, to originate the variance ratio tests, because they developed tests of random walks under alternative assumptions of homoskedasticity and heteroskedasticity on the terms of the function that indicated the error. The stock price data in the study were obtained from the DataStream database and included closing price indices for the Chinese stock market. The four Chinese stock market price indices were the Shanghai A and B-share index and Shenzhen A and B-share index. The sample period covered nearly ten years, from 1996 to 2005 .

The working paper adopted different variance ratio tests to stress the data, including Andrew W. Lo and A. Craig MacKinlay's (1988) test, Chow and Denning's (1993) test and Wright's (2000) test, to investigate the weak-form EMH of the Chinese markets.

All the analyses revealed evidence of weak-form EMH, and that the changes in market efficiency were likely to result from the regulatory transformation associated with the reform of restrictions on the B-share market.

In "Testing Market Efficiency: Empirical Evidence From Developed Markets of Asia Pacific" (2012), the authors Nisar and Hanif, aimed to verify the efficient market hypothesis on the seven major stock exchanges in the Asia-Pacific area, including Japan, China, Korea, Hong Kong, Australia, India and Pakistan.

After an introduction where they explained the characteristic of all the markets, the authors declared the aim of the paper, which was to investigate the week-form of EMH to help local and foreign investors to design their investment strategies according to the nature of the markets.

The study presents a literature review, followed by a Purpose and Methodology section and subsequent Findings, Analysis and Conclusion sections. 
The entire paper was focused on Fama's (1970) work on the efficient capital markets, and the methodology used was based on the empirical analysis using secondary data. The indexes considered were: Nikke N225 for Japan, Shanghai Composite for China, Kospi Composite for Korea, Hang Seng Index for Hong Kong, All Ordinaries ASX for Australia, KSE-100 for Pakistan and BSE-SENEX for India.

Every market was considered on a daily, weekly, and monthly basis, in the period from 1997 to 2011. After the calculation of daily, weekly, and monthly returns, the author first calculated the continuous compounded annual rate of return and then ran a test to analyse the market efficiency. Subsequently, he applied the Wald-Wolfowitz's test and the Variance Ratio Test, based on Andrew W. Lo and A. Craig MacKinlay's (1988) and Chow and Denning's (1993) articles, where simple and multiple variation tests were performed, to answer the question of whether the asset prices or returns were predictable or not.

After applying the variance ratio test, the authors got two types of results, one was a joint test, which was the result of multiple variance ratio tests, and the other was represented by individual period results that were the result of a static variance ratio test. They focused on the results of multiple variance ratio tests because they explained the joint probability.

After the application of runs test on all the stock exchanges, the authors found that Shanghai Composite, KSE-100 and BSE SENEX were not weakforms of efficient markets because their successive returns did not generate randomly. Whereas Nikke N225, Kospi Composite, Hang Seng Index HIS and All Ordinaries ASX were a weak form of efficient markets because their successive return series generated randomly.

In their conclusions, the authors gave some important recommendations: firstly, all policymakers had to realise the importance of market efficiency; secondly, they had to develop and provide an efficient market to investors; thirdly, they had to reform the whole system of trading in the stock market introducing a massive audit and information technology to allow all the actors to receive relevant information.

After the 2005-2006 reform, three Italian researchers, Beltratti, Bortolotti and Caccavaio (2016), decided to study the reaction of stock returns and trading volumes to the transformation of non-tradable shares (NTS) into tradable shares (TS). 
Until 2003, on the Chinese stock market, A-shares could only be traded by domestic investors, while B-shares were denominated in foreign currencies and reserved to foreign investors. In April 2005, the China Securities Regulatory Commission announced a pilot program to transform nontradable shares into tradable ones ( $\mathrm{Li}$ et al., 2011). In the final version of this reform, the NTS holders negotiated the compensation to pay to TS holders, after two suspensions of trade and the approval of the negotiation. The payment could be made in various ways: new shares offered by NTS holders, new shares offered by the company, in cash or warrants.

The data used for the empirical tests were extracted from the DataStream database, Shenzhen GTA Information Technology Co Limited and Nomura Institute of Capital Market Research. The original sample involved 1440 companies, but it was later reduced because some of the companies had discrepancies from the other, like suspensions from trading for unspecified reasons, unclear negotiation of compensation paid and mismatch of datasets. The remaining sample was composed of 1007 companies to study.

The methodology used by the authors was the study of the residual from a pricing model. Beltratti, Bortolotti and Caccavaio measured the variance of the sample in three ways, firstly using the Campbell LOMAC (1997) method, the cross-sectional variance across mean cumulative and average abnormal returns of the various companies, and the Brown and Warner (1985) work.

The results obtained showed: abnormal positive returns in the past two days before the first suspension, caused by the non-diversifiable compensation risk; abnormal positive returns in the ten days after the initial readmission, possibly caused by a delayed reaction to positive compensation surprise; price drop after the second readmission. This outcome suggests that the speculation, though present, is not dominant and that Chinese market efficiency progresses over time ('Stock market efficiency in China: Evidence from the split-share reform', 2016).

The last academic paper studied, written by Han, Wang and Xu (2019), examined the daily return series from the Chinese markets. The authors used the MF-DFA methodology, introduced by Kantelhardt (2002), a powerful tool to detect and quantify multifractal properties in the markets. The analysis is composed of five steps that conduct to a final value. If the multifractal level is negatively correlated with the market efficiency, it is necessary to look at MD. The higher the MD value is, the less efficient the stock market is. There are two possible causes of multifractality: long-range correlation for small and large fluctuations and the fat-tailed distribution of the series. The 
data used were the Shanghai Stock Exchange Composite Index, the Shanghai-Shenzhen 300 Index, the Shenzhen Stock Exchange Component Index, and the CSI Small-cap 500 Index from 2000 to 2018.

The authors employed indices because they synthetically reflected the overall quotations and trends in the markets. Besides Han, Wang, and Xu also investigated sub-samples to give strength to their hypotheses. The empirical results indicated that the four index return series showed multifractal characteristics, resulting in inefficiency in stock markets. The assumptions raised by the authors suggested that the inefficiency could be economically caused by government intervention and other market behaviour during the stock crash in 2015. They recommended investigating the causes of these inefficiencies because, in the long run, they may be critical for the sustainable development of the Chinese capital market. The proposed solutions were: to promote the reform of the stock market to maintain it sustainable, apply progressive reform that could reduce the impact of external events, optimize the investor structure and reduce the excessive government administrative intervention to improve the operational and functional efficiency of the stock market. 


\begin{tabular}{|c|c|c|}
\hline Study & Mookerjee and Yu (1999) & Cajueiro and Tabak (2004) \\
\hline $\begin{array}{l}\text { Data } \\
\text { reference } \\
\text { period }\end{array}$ & $\begin{array}{l}\text { SHI: } \\
\text { 12/19/1990 - 12/17/1993 } \\
\text { SZI: } \\
\text { 04/03/1991 - 12/17/1993 }\end{array}$ & $10 / 01 / 1992-12 / 31 / 2000$ \\
\hline Purpose & $\begin{array}{l}\text {-Test the market efficiency of newly } \\
\text { established stock markets in Shanghai } \\
\text { and Shenzhen. } \\
\text {-Test the presence of seasonal } \\
\text { fluctuations in stock markets. }\end{array}$ & $\begin{array}{l}\text { Test the efficient stock market hypothesis } \\
\text { (EMH) for China, Hong Kong and } \\
\text { Singapore to demonstrate the long-run } \\
\text { dependence approach. }\end{array}$ \\
\hline Methods & $\begin{array}{l}\text { For market efficiency tests: random-walk } \\
\text { simulated trend compared with } \\
\text { effectively trend based on market } \\
\text { efficiency (EMH), long-term returns, and } \\
\text { behavioural finance (Fama, 1998). } \\
\text { For seasonal fluctuations: random-walk } \\
\text { model and empirical seasonal anomalies } \\
\text { comparison. }\end{array}$ & $\begin{array}{l}\text { Hurst's exponent calculated by the } \mathrm{R} / \mathrm{S} \\
\text { analysis to determine the measure of long- } \\
\text { range dependence. }\end{array}$ \\
\hline Data & $\begin{array}{l}\text { Daily stock price data from Shanghai and } \\
\text { Shenzhen Securities Exchanges. }\end{array}$ & $\begin{array}{l}\text { Daily stocks price for the Chinese (A and B } \\
\text { stocks), Hong Kong and Singapore markets } \\
\text { with Bloomberg data. }\end{array}$ \\
\hline $\begin{array}{l}\text { Results and } \\
\text { conclusions }\end{array}$ & $\begin{array}{l}\text { The empirical evidence marshalled in } \\
\text { Mookerjee and Yu work rejects the } \\
\text { random walk implications of the efficient } \\
\text { market hypothesis. Besides, the results } \\
\text { document significant weekend and } \\
\text { holiday effects. The inefficiencies of } \\
\text { China's equity markets are due to several } \\
\text { factors: restricted supply of stocks; } \\
\text { excessive volatility due to policy changes } \\
\text { by the authorities and scarcity of } \\
\text { information causes cognitive bias. }\end{array}$ & $\begin{array}{l}\text { The authors find evidence that the three } \\
\text { markets show long-term dependence. The } \\
\text { results suggest that more research is needed } \\
\text { on testing for long-term dependence. }\end{array}$ \\
\hline
\end{tabular}

\begin{tabular}{|c|c|c|}
\hline Study & da Veiga, Chan, and McAleer (2008) & Hung (2009) \\
\hline $\begin{array}{l}\text { Data } \\
\text { reference } \\
\text { period }\end{array}$ & $10 / 06 / 1992-08 / 10 / 2005$ & 04/05/1996-12/30/2005 \\
\hline Purpose & $\begin{array}{l}\text { Analyse the time-varying conditional } \\
\text { correlations between Chinese A and B- } \\
\text { share returns using the DDC model } \\
\text { (Engle, 2002). }\end{array}$ & $\begin{array}{l}\text { Test the weak-form efficient market } \\
\text { hypothesis of A and B-shares on Shanghai } \\
\text { and Shenzhen exchanges and the influence } \\
\text { of the investment restriction of B-share } \\
\text { markets on market efficiency before and } \\
\text { after the regulatory changes in } 2001 \text {. }\end{array}$ \\
\hline Methods & $\begin{array}{l}\text { The DCC model was used to estimate } \\
\text { the dynamic conditional correlations } \\
\text { between A and B-shares for Chinese } \\
\text { investors. }\end{array}$ & $\begin{array}{l}\text { Use single and multiple variance ratio tests, } \\
\text { which combined the methods of Andrew } \\
\text { W. Lo and A. Craig MacKinlay (1988), } \\
\text { Chow and Denning (1993) and Wright } \\
\text { (2000), to investigate the weak-form of the } \\
\text { EMH of the A- and B-shares markets of } \\
\text { Shanghai and Shenzhen exchanges in } \\
\text { Chinese stock market. }\end{array}$ \\
\hline
\end{tabular}




\begin{tabular}{|c|c|c|}
\hline Data & $\begin{array}{l}\text { Daily returns of Shanghai A and B-share } \\
\text { indexes and Shenzhen A and B-share } \\
\text { indexes. }\end{array}$ & $\begin{array}{l}\text { Daily stock market prices, for a total of } \\
2344 \text { observations for each of four stock } \\
\text { index price series from DataStream. }\end{array}$ \\
\hline $\begin{array}{l}\text { Results and } \\
\text { conclusions }\end{array}$ & $\begin{array}{l}\text { The results show that the conditional } \\
\text { correlations increased substantially } \\
\text { following the B-share market reform, } \\
\text { whereby Chinese investors were } \\
\text { permitted to purchase B-shares. The } \\
\text { results are important because, as the } \\
\text { correlation between Chinese A and B- } \\
\text { shares approaches to } 1 \text {, the benefits } \\
\text { of diversifying across both types of } \\
\text { shares diminishes and investors should } \\
\text { focus on the class of } \\
\text { shares that will yield the greatest } \\
\text { expected returns. }\end{array}$ & $\begin{array}{l}\text { For the whole sample period, it is } \\
\text { consistently found that SHBI, SZAI and } \\
\text { SZBI are not supported } \\
\text { by the weak-form EMH basing on the } \\
\text { single variance ratio test. For the analyses } \\
\text { of sub-samples, the conclusions during the } \\
\text { first sub-period are the same as the } \\
\text { whole sample period. However, except for } \\
\text { SHAI, opposite results are found for the } \\
\text { two subsamples. }\end{array}$ \\
\hline
\end{tabular}

\begin{tabular}{|c|c|c|c|}
\hline Study & Nisar and Hanif (2012) & $\begin{array}{l}\text { Beltratti, Bortolotti, and } \\
\text { Caccavaio (2016) }\end{array}$ & Han, Wang and $\mathrm{Xu}$ (2019) \\
\hline $\begin{array}{l}\text { Data } \\
\text { reference } \\
\text { period }\end{array}$ & $\begin{array}{l}07 / 01 / 2000- \\
06 / 30 / 2011\end{array}$ & 03/01/2004-02/28/2007 & 01/04/2000- 09/11/2018 \\
\hline Purpose & 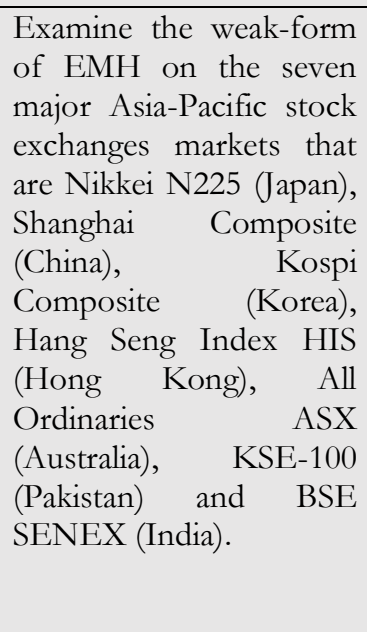 & $\begin{array}{l}\text { Study the reaction of stock } \\
\text { returns and trading } \\
\text { volumes to the 2005-2006 } \\
\text { structural reform which } \\
\text { allowed the transformation } \\
\text { of non-tradable shares } \\
\text { (NTS) into tradable shares } \\
\text { (TS) through the payment } \\
\text { of compensation to TS } \\
\text { holders. }\end{array}$ & $\begin{array}{l}\text { Examine the daily return } \\
\text { series of four main indices } \\
\text { (SSE-SZSE-SHSE-CSI500) } \\
\text { in the Chinese stock market. } \\
\text { Compare the multifractality } \\
\text { degrees of the four indices } \\
\text { in three sub-samples divided } \\
\text { by the } 2015 \text { stock market } \\
\text { crash and the effect of the } \\
2015 \text { stock market crash on } \\
\text { market efficiency from the } \\
\text { statistical and fractal } \\
\text { perspectives, which has } \\
\text { theoretical and practical } \\
\text { significance in the } \\
\text { application of EMH. }\end{array}$ \\
\hline Methods & $\begin{array}{l}\text { This study is conducted } \\
\text { in an empirical format by } \\
\text { using secondary data. The } \\
\text { test of Wald-Wolfowitz } \\
\text { and the Variance Ratio } \\
\text { Test are used to test the } \\
\text { market efficiency. }\end{array}$ & $\begin{array}{l}\text { The event study uses } \\
\text { residuals from a pricing } \\
\text { model. Regression could } \\
\text { not be used because of the } \\
\text { trading suspension. The } \\
\text { authors simulate three } \\
\text { artificial time series } \\
\text { obtained with the MCARs } \\
\text { method (Campbell et al., } \\
\text { 1997), calculating the } \\
\text { variance with the CLM } \\
\text { (Asquith, 1983) and they } \\
\text { test the robustness of that } \\
\text { estimator under the null } \\
\text { hypothesis of no abnormal } \\
\text { returns. }\end{array}$ & $\begin{array}{l}\text { The method of multifractal } \\
\text { analysis was used to study } \\
\text { price fluctuation in China's } \\
\text { stock market; the MF-DFA } \\
\text { method was applied to } \\
\text { analyse the complexity and } \\
\text { dynamics of financial } \\
\text { markets. }\end{array}$ \\
\hline
\end{tabular}




\begin{tabular}{|c|c|c|c|}
\hline Data & $\begin{array}{l}\text { The daily, weekly, and } \\
\text { monthly closing index } \\
\text { values of Nikke N225, } \\
\text { Shanghai Composite, } \\
\text { Kospi Composite, Hang } \\
\text { Seng Index HIS, All } \\
\text { Ordinaries ASX, KSE- } \\
100 \text { and BSE SENEX are } \\
\text { used to calculate the daily, } \\
\text { weekly and monthly } \\
\text { returns. }\end{array}$ & $\begin{array}{l}\text { Three data sources for the } \\
\text { empirical work were used: } \\
\text { DataStream, Shenzhen } \\
\text { GTA Information } \\
\text { Technology Co Limited } \\
\text { and the } \\
\text { data kindly provided by the } \\
\text { Nomura Institute of } \\
\text { Capital Market Research. } \\
\text { The original sample } \\
\text { involved } 1440 \text { companies, } \\
\text { but } 185 \text { were later dropped. }\end{array}$ & $\begin{array}{l}\text { The data source is the } \\
\text { RESSET database. The } \\
\text { selected SSE Index and the } \\
\text { SZSE Index reflect the } \\
\text { quotations and the trends of } \\
\text { the Shanghai and Shenzhen } \\
\text { markets, respectively, while } \\
\text { the SHSE-SZSE300 index } \\
\text { synthetically reflects the } \\
\text { overall quotations and } \\
\text { trends of the Shanghai and } \\
\text { Shenzhen markets. }\end{array}$ \\
\hline $\begin{array}{l}\text { Results and } \\
\text { conclusions }\end{array}$ & $\begin{array}{l}\text { After applying the Test of } \\
\text { Wald-Wolfowitz and } \\
\text { Variance Ratio Test, it is } \\
\text { found in the process that } \\
\text { three out of seven } \\
\text { developed stock markets } \\
\text { of Asia Pacific do not } \\
\text { follow Random-walk and } \\
\text { hence Nikke N225 } \\
\text { (Japan), Kospi } \\
\text { Composite (Korea), } \\
\text { Hang Seng Index HIS } \\
\text { (Hong Kong) and All } \\
\text { Ordinaries ASX } \\
\text { (Australia) } \\
\text { exchanges meet the weak } \\
\text { form of EMH. }\end{array}$ & $\begin{array}{l}\text { The main results are: } \\
\text { abnormal returns are } \\
\text { positive in the two days } \\
\text { before the first suspension; } \\
\text { abnormal returns are } \\
\text { positive in the ten days } \\
\text { after } \\
\text { the first readmission; prices } \\
\text { drop after the second } \\
\text { readmission; volume } \\
\text { increases to record levels } \\
\text { during and after the } \\
\text { reform, even accounting } \\
\text { for the increase in the } \\
\text { supply of shares assigned } \\
\text { as compensation. }\end{array}$ & $\begin{array}{l}\text { The empirical results } \\
\text { indicated that the four-index } \\
\text { return series exhibit } \\
\text { multifractal characteristics } \\
\text { with different levels in the } \\
\text { sample, resulting in } \\
\text { inefficiency in the stock } \\
\text { markets. This inefficiency } \\
\text { may be caused by } \\
\text { government intervention } \\
\text { and other market } \\
\text { behaviours during or after } \\
\text { the stock crash. }\end{array}$ \\
\hline
\end{tabular}




\section{Literature Review on Regulatory Changes}

As seen previously, China went through a long period of economic and social reforms that necessarily led to changes in the lifestyle and way of doing business. To investigate the effects that occurred over time, three academic papers have been selected: they show how the politicises changed these characteristics over time. The aspects examined were: the effect on the social and economic inequalities in the Chinese provinces, how the Chinese stock market could change after the improvement of minority-shareholder protection, and what solutions could be adopted to overcome the information problems that plagued the Chinese economy.

In the post-1978 reform's era, Tsui (1996) investigated the province inequality condition using the Gross Domestic Product (GDP) data comparison. Further analysis was conducted by decomposing GDP into subsectors to understand their influence.

Tsui covered the period between 1978 to 1989 and measured different indices to test the robustness of his hypothesis. The most used indexes were the Gini coefficient and the Coefficient of Variation. By decomposing the GDP into primary, secondary, and tertiary sectors, the authors obtained the same results of macro-analysis: the Chinese inequalities decreased in the first five years of the studied period and then rose again in the following five years. The study reveals that urban industrial-economic reforms, fiscal decentralisation policies, the rapid development of rural industries in the coastal region, the rapid growth of the tertiary sector and the flow of foreign capital in the enriched provinces seem to be responsible for the rise of interprovincial disparities in the second half of the 1980s.

Since 1994, the Chinese administration has implemented policies that could potentially reduce this problem, such as a new local-central tax sharing system. Since 2000 three new regulations, aimed at reducing expropriation from minority shareholders by controlling block-holders, have been influencing the Chinese stock market. The changes in regulations were motivated by China's entrance into the World Trade Organization in 2001 (Berkman, Cole and Fu, 2010).

In Berkman, Cole, and Fu's works, the authors used the standard event-study methodology to analyse the link between investor protection and firm value. To reduce the potential external events that could influence the results, the authors used cross-sectional regression and studied the value changes for the selected firms before and after the regulatory changes. 
The results showed that firms with higher levels of expropriation from minority shareholders excessively benefit from the regulation and that the more the firms are influenced by the State, the less efficient the reform is.

To analyse how China could overcome the information problem that involves market efficiency, Leutert (2020) studied the correlation between government adopted strategies and their implementation.

China used the Policy feedback loops to control the level of implementation and the effects of the reforms.

There is a relationship between improvisation, experimentation and multilevel government that helps to adapt the strategies to the context, called "Learning by Doing". Enterprise interactions with the Chinese government are more useful than ever to help develop and implement policies in biotechnology, urban transportation, and rural development (Leutert, 2020). 


\begin{tabular}{|c|c|c|c|}
\hline Study & (Tsui, 1996) & $\begin{array}{l}\text { (Berkman, Cole and Fu, } \\
2010)\end{array}$ & (Leutert, 2020) \\
\hline Data & $\begin{array}{l}\text { (final version March 1995) } \\
\text { Published } 1996\end{array}$ & $12 / 2010$ & $08 / 23 / 2020$ \\
\hline Purpose & $\begin{array}{l}\text { Explore two issues: the } \\
\text { trend of interprovincial } \\
\text { inequality in the post-1978 } \\
\text { reform era in China and } \\
\text { the factors behind the } \\
\text { dynamics of } \\
\text { interprovincial inequality. }\end{array}$ & $\begin{array}{l}\text { Examine the wealth effects } \\
\text { of three regulatory changes } \\
\text { designed to improve } \\
\text { minority-shareholder } \\
\text { protection in Chinese stock } \\
\text { markets using the value of a } \\
\text { firm's related-party } \\
\text { transactions as an inverse } \\
\text { proxy for the quality of } \\
\text { corporate governance. }\end{array}$ & $\begin{array}{l}\text { Find the relationship } \\
\text { between government } \\
\text { improvisation, } \\
\text { experimentation, and } \\
\text { multi-level governance. } \\
\text { Identify how China did } \\
\text { overcome information } \\
\text { problems and } \\
\text { institutional gaps to } \\
\text { successfully implement } \\
\text { market reforms in its } \\
\text { economy. }\end{array}$ \\
\hline $\begin{array}{l}\text { Main } \\
\text { argument } \\
\text { and } \\
\text { methodology }\end{array}$ & $\begin{array}{l}\text { National income data } \\
\text { from the socialist national } \\
\text { accounting system are } \\
\text { used to identify the impact } \\
\text { of interprovincial resource } \\
\text { flows on interprovincial } \\
\text { inequalities. The findings } \\
\text { seem to suggest } \\
\text { a relative decline in the } \\
\text { role of redistributive } \\
\text { budgetary transfers. }\end{array}$ & $\begin{array}{l}\text { Standard event-study } \\
\text { methodology to analyse the } \\
\text { link between investor } \\
\text { protection and firm value. In } \\
\text { addition to reducing } \\
\text { potential endogeneity } \\
\text { problems inherent in the use } \\
\text { of cross-sectional } \\
\text { regressions that relate } \\
\text { investor protection to firm } \\
\text { value, event studies analyse } \\
\text { the change in value for the } \\
\text { same sample of firms before } \\
\text { and after the changes in the } \\
\text { regulatory environment. }\end{array}$ & $\begin{array}{l}\text { Examine policy } \\
\text { feedback loops in } \\
\text { China's state-owned } \\
\text { economy analysing three } \\
\text { reforms: contract } \\
\text { responsibility system, } \\
\text { cost control system, } \\
\text { reform and procurement } \\
\text { management system } \\
\text { reforms. } \\
\text { The methodology used } \\
\text { to conduct the analysis is } \\
\text { traced to three decades } \\
\text { of data. }\end{array}$ \\
\hline $\begin{array}{l}\text { Results and } \\
\text { conclusions }\end{array}$ & $\begin{array}{l}\text { Using the decomposed } \\
\text { GDP, the author shows } \\
\text { that interprovincial } \\
\text { inequality decreased in the } \\
\text { first half of the } 1980 \text { s but } \\
\text { started to increase in the } \\
\text { second half. Urban } \\
\text { industrial-economic fiscal } \\
\text { reforms, } \\
\text { decentralization, the rapid } \\
\text { development of rural } \\
\text { industries in the coastal } \\
\text { region, the rapid growth } \\
\text { of the tertiary sector and } \\
\text { the flow of foreign capital } \\
\text { in the richer provinces } \\
\text { seem to be responsible for } \\
\text { the rise in interprovincial } \\
\text { disparities in the second } \\
\text { half of the 1980s. The new } \\
\text { policies applied can } \\
\text { potentially reduce the } \\
\text { income gap between rich } \\
\text { and poor provinces. }\end{array}$ & $\begin{array}{l}\text { Authors found that firms } \\
\text { with higher levels of } \\
\text { expropriation from minority } \\
\text { shareholders } \\
\text { disproportionately benefit } \\
\text { from the regulations in firms } \\
\text { with lower levels of } \\
\text { expropriation from minority } \\
\text { shareholders. They examine } \\
\text { whether securities-market } \\
\text { regulations to improve } \\
\text { minority-shareholder } \\
\text { protection in China can be } \\
\text { effective. Authors suggest } \\
\text { that the regulations benefit } \\
\text { could be for firms that do } \\
\text { not have close ties to the } \\
\text { government. }\end{array}$ & $\begin{array}{l}\text { Leutert identifies the } \\
\text { micro-level mechanisms } \\
\text { underpinning broader } \\
\text { processes of policy } \\
\text { experimentation and } \\
\text { implementation. The } \\
\text { enterprise interactions } \\
\text { with the Chinese } \\
\text { government are } \\
\text { important today more } \\
\text { than ever, as state- } \\
\text { owned, and private } \\
\text { enterprises alike } \\
\text { increasingly partner with } \\
\text { the Chinese authorities } \\
\text { to develop and } \\
\text { implement policies in } \\
\text { biotechnology, urban } \\
\text { transportation, rural } \\
\text { development and many } \\
\text { other areas. }\end{array}$ \\
\hline
\end{tabular}




\section{Results}

It is clear from the analysis that the Chinese financial structure has been subject to considerable reforms that have made foreign investors doubtful about the market stability.

A market is defined as efficient when it has an efficient mix of investment strategies to permit the investor to differentiate the market risk. A balanced decision mix provides stable and efficient financial markets. Investors consider a market as well balanced by looking at three fundamental strategies: firstly, they examine the value-investment, involving assets generating economic value during the investment length; secondly, they consider the relative profit of the investment, including arbitrage; thirdly, they may contemplate speculation investments. The Chinese market does not have good-balanced investor strategies because credible data and low transaction costs are not effortlessly available in China. There are few value investors in China because most of the information they need to make investment decisions is not available, such as reliable data, trustworthy corporate frameworks, and predictable government behaviour. This causes low-quality information; hence value-investors decide to avoid the market. Should they overcome the difficulty in finding the right information, the variety of noneconomic factors would severely affect the rates required by investors to see their investment risk remunerated. Thus, the shareholder and the stockholder must be speculators if they expect to receive profits (Pettis, 2013).

The Chinese government could reduce the magnitude of speculative trends through the reduction of non-economic variables that influence investors' choices, the improvement of corporate transparency and the rise in the quality of available national economic information, to attract every category of investors.

\section{References}

- Andrew W. Lo and A. Craig MacKinlay (1988) Stock Market Prices Do Not Follow Random Walks: Evidence From a Simple Specification Test. National Bureau of Economic Research, Inc. Available at: https://ideas.repec.org/p/nbr/nberwo/2168.html. 
- Asquith, P. (1983) 'Merger bids, uncertainty, and stockholder returns', journal of Financial Economics, 11(1-4), pp. 51-83.

- Berkman, H., Cole, R. A. and Fu, L. J. (2010) 'Political Connections and MinorityShareholder Protection: Evidence from Securities-Market Regulation in China', The Journal of Financial and Quantitative Analysis, 45(6), pp. 1391-1417. Available at: https://www.jstor.org/stable/27919571 (Accessed: 16 October 2020).

- Brown, S. J. and Warner, J. B. (1985) 'Using daily stock returns', Journal of Financial Economics, 14(1), pp. 3-31. doi: 10.1016/0304-405X(85)90042-X.

- Cajueiro, D. O. and Tabak, B. M. (2004) 'Evidence of long range dependence in Asian equity markets: the role of liquidity and market restrictions', Physica A: Statistical Mechanics and its Applications, 342(3-4), pp. 656-664. doi: 10.1016/j.physa.2004.05.034.

- Campbell, J. Y. et al. (1997) The econometrics of financial markets. princeton University press.

- Chow, K. V. and Denning, K. C. (1993) 'A simple multiple variance ratio test', Journal of Econometrics, 58(3), pp. 385-401.

- Chui, A. C. and Kwok, C. C. (1998) 'Cross-autocorrelation between A shares and B shares in the Chinese stock market', Journal of financial research, 21(3), pp. 333353.

- Degutis, A. and Novickyté, L. (2014) 'THE EFFICIENT MARKET HYPOTHESIS: A CRITICAL REVIEW OF LITERATURE AND METHODOLOGY', 93.

- Engle, R. (2002) 'Dynamic Conditional Correlation: A Simple Class of Multivariate Generalized Autoregressive Conditional Heteroskedasticity Models', Journal of Business \& Economic Statistics, 20(3), pp. 339-350. Available at: https://www.jstor.org/stable/1392121 (Accessed: 12 October 2020).

- Fama, E. F. (1970) 'Efficient capital markets: A review of theory and empirical work', The journal of Finance, 25(2), pp. 383-417.

- Fama, E. F. (1998) 'Market efficiency, long-term returns, and behavioral finance', Journal of Financial Economics, p. 24.

- Fortune, P. and others (1991) 'Stock market efficiency: an autopsy?', New England Economic Review, pp. 17-40.

- Grossman, S. J. and Stiglitz, J. E. (1976) 'Information and competitive price systems', The American Economic Review, 66(2), pp. 246-253. 
- Han, C., Wang, Y. and Xu, Y. (2019) 'Efficiency and Multifractality Analysis of the Chinese Stock Market: Evidence from Stock Indices before and after the 2015 Stock Market Crash', Sustainability, 11(6), p. 1699. doi: 10.3390/su11061699.

- Hung, J.-C. (2009) 'Deregulation and liberalization of the Chinese stock market and the improvement of market efficiency', The Quarterly Review of Economics and Finance, 49(3), pp. 843-857. doi: 10.1016/j.qref.2009.04.005.

- Kantelhardt, J. W. et al. (2002) 'Multifractal detrended fluctuation analysis of nonstationary time series', Physica A: Statistical Mechanics and its Applications, 316(14), pp. 87-114.

- Leutert, W. (2020) 'Innovation through iteration: Policy feedback loops in China's economic reform', World Development, 138, p. 105173. doi: 10.1016/j.worlddev.2020.105173.

- Li, K. et al. (2011) 'Privatization and Risk Sharing: Evidence from the Split Share Structure Reform in China', Review of Financial Studies, 24(7), pp. 2499-2525. doi: $10.1093 / \mathrm{rfs} / \mathrm{hhr} 025$.

- Mookerjee, R. and Yu, Q. (1999) 'An empirical analysis of the equity markets in China', Review of Financial Economics, 8(1), pp. 41-60. doi: 10.1016/S10583300(99)00006-3.

- Nisar, S. and Hanif, M. (2012) Testing Market Efficiency: Empirical Evidence from Developed Markets of Asia Pacific. SSRN Scholarly Paper ID 1983960. Rochester, NY: Social Science Research Network. doi: 10.2139/ssm.1983960.

- Pettis, M. (2013) Why China's financial markets are inefficient. Available at: https://www.theaustralian.com.au/business/business-spectator/newsstory/why-chinas-financial-markets-areinefficient/8781b8bf2b00110590134144c00720b3 (Accessed: 15 November 2020).

- Shiller, R. J. (2003) 'From efficient markets theory to behavioral finance', Journal of economic perspectives, 17(1), pp. 83-104.

- Shiller, R. J. (2013) 'Sharing Nobel Honors, and Agreeing to Disagree (Published 2013)', The New York Times, 26 October. Available at: https://www.nytimes.com/2013/10/27/business/sharing-nobel-honors-andagreeing-to-disagree.html (Accessed: 11 November 2020).

- 'Stock market efficiency in China: Evidence from the split-share reform' (2016) The Quarterly Review of Economics and Finance, 60, pp. 125-137. doi: 10.1016/j.qref.2015.11.002. 
- Tsui, K. (1996) 'Economic reform and interprovincial inequalities in China', Journal of Development Economics, 50(2), pp. 353-368. doi: 10.1016/S03043878(96)00406-3.

- da Veiga, B., Chan, F. and McAleer, M. (2008) 'Evaluating the impact of market reforms on Value-at-Risk forecasts of Chinese A and B shares', Pacific-Basin Finance Journal, 16(4), pp. 453-475. doi: 10.1016/j.pacfin.2007.08.001.

- Wright, J. H. (2000) 'Alternative variance-ratio tests using ranks and signs', Journal of Business \& Economic Statistics, 18(1), pp. 1-9. 